\title{
Evaluation of the protective immunogenicity of the $N, P, M, N V$ and $G$ proteins of infectious hematopoietic necrosis virus in rainbow trout Oncorhynchus mykiss using DNA vaccines
}

\author{
S. Corbeil ${ }^{1,2}$, S. E. LaPatra ${ }^{3}$, E. D. Anderson ${ }^{4}$, J. Jones ${ }^{3}$, B. Vincent ${ }^{3}$, Y.-L. Hsu ${ }^{5}$, \\ G. Kurath ${ }^{2, *}$ \\ 'Department of Pathobiology, University of Washington, Box 357238, Seattle, Washington 98195-7238, USA \\ ${ }^{2}$ Western Fisheries Research Center, 6505 NE, 65th St., Seattle, Washington 98115-5016, USA \\ ${ }^{3}$ Clear Springs Foods Inc., Research Division, PO Box 712, Buhl, Idaho 83316, USA \\ ${ }^{4}$ Department of Biochemistry, Microbiology and Molecular Biology, University of Maine, Orono, Maine 04469-5753, USA \\ ${ }^{5}$ Institute of Zoology, Academia Sinica, Nankang 11529, Taipei, Taiwan, ROC
}

\begin{abstract}
The protective immunogenicity of the nucleoprotein (N), phosphoprotein (P), matrix protein (M), non-virion protein (NV) and glycoprotein (G) of the rhabdovirus infectious hematopoietic necrosis virus (IHNV) was assessed in rainbow trout using DNA vaccine technology. DNA vaccines were produced by amplifying and cloning the viral genes in the plasmid pCDNA 3.1. The protective immunity elicited by each vaccine was evaluated through survival of immunized fry after challenge with live virus. Neutralizing antibody titers were also determined in vaccinated rainbow trout Oncorhynchus mykiss fry (mean weight $2 \mathrm{~g}$ ) and $150 \mathrm{~g}$ sockeye salmon Oncorhynchus nerka. The serum from the $150 \mathrm{~g}$ fish was also used in passive immunization studies with naive fry. Our results showed that neither the internal structural proteins ( $N, P$ and $M$ ) nor the NV protein of IHNV induced protective immunity in fry or neutralizing antibodies in fry and $150 \mathrm{~g}$ fish when expressed by a DNA vaccine construct. The $G$ protein, however, did confer significant protection in fry up to $80 \mathrm{~d}$ postimmunization and induced protective neutralizing antibodies. We are currently investigating the role of different arms of the fish immune system that contribute to the high level of protection against IHNV seen in vaccinated fish
\end{abstract}

KEY WORDS: Infectious hematopoietic necrosis virus - Rhabdovirus - DNA vaccines - Rainbow trout

\section{INTRODUCTION}

Infectious hematopoietic necrosis virus (IHNV) is the most important viral pathogen of salmonids in North America. Originally enzootic on the west coast of North America, IHNV has been detected in other areas of the world where salmonid fishes are found. Significant economic impacts by IHNV on public and private aquaculture have motivated researchers to work towards the development of a safe and effective vaccine. DNA vaccines have successfully been used to protect

•Corresponding author. E-mail: gael_kurath@usgs.gov many species against various pathogens. In salmon and trout, the glycoprotein genes of pathogenic rhabdoviruses, including IHNV and viral haemorragic septicemia virus (VHSV) (Anderson et al. 1996b, Boudinot et al. 1998, Lorenzen et al. 1998), have been shown to be protective when used in a DNA vaccine. Other gene products, however, have been given little attention because most vaccines aim at presenting surface proteins to the host immune system. It is known that cytotoxic T-lymphocytes (CTL) in both mice and humans play an important role in the immune response by recognizing epitopes derived from conserved internal virion proteins (Paul 1999). The role of IHN viral proteins as inducers of CTL activity is unknown. A vaccine 
able to stimulate CTLs in fish may confer protection against different strains of IHNV and would be a useful tool in the study of viruses and their interaction with the fish immune system.

Recent studies have shown that DNA vaccines containing internal viral proteins such as the core protein of lymphocytic choriomeningitis virus (Yokoyama et al. 1995), or the nucleoprotein of either the measle virus (Fooks et al. 1996) or the influenza virus (Ulmer et al. 1993), are capable of stimulating both humoral and T-cell responses in mice. Furthermore, Lorenzen et al. (1998) demonstrated in rainbow trout that a DNA vaccine containing only the nucleocapsid $(\mathrm{N})$ gene of VHSV was able to induce some level of protective immunity against viral challenge. In contrast, a DNA vaccine encoding the $\mathrm{N}$ gene of IHNV was shown not to induce antibody response or protection in rainbow trout against viral challenge (Anderson et al. 1996b). This inconsistency between these studies prompted us to re-test, with new vaccine constructs, the ability of individual viral proteins to protect rainbow trout against an immersion challenge with IHNV.

The objective of this study was to evaluate the immunogenicity of the nucleocapsid protein $(\mathrm{N})$, phosphoprotein $(\mathrm{P})$, matrix protein $(\mathrm{M})$ and non-virion protein (NV) in comparison to the glycoprotein (G) of IHNV in rainbow trout Oncorhynchus mykiss. DNA vaccines were produced by inserting the genes coding for the various viral proteins in the plasmid pCDNA 3.1 (Invitrogen, Carlsbad, CA). The protective immunity of each vaccine was evaluated by measuring the survival of immunized fry after challenge with live virus. Neutralizing antibody titers were also determined and the passive immunization of naïve fry was performed to further assess potential protective mechanisms.

\section{MATERIALS AND METHODS}

Virus and cell culture. An epithelioma papulosum cyprini (EPC) cell line (Fijan et al. 1983) and chinook salmon embryo (CHSE-214) cell line (Lannan et al. 1984) were used for the propagation of IHNV. Cells were maintained at 15 to $17^{\circ} \mathrm{C}$ in minimum essential medium (MEM) (GIBCO, Grand Island, NY) supplemented with $10 \%$ fetal bovine serum (Hyclone, Logan, Utah) and $2 \mathrm{mM}$ L-glutamine (GIBCO, Grand Island, NY). IHNV isolate 220-90 (LaPatra et al. 1991a) was used to infect cells at a multiplicity of infection of 0.1 and incubated at 15 to $17^{\circ} \mathrm{C}$. Quantification of virus used in fish challenge or isolated from dead fish was performed by plaque assay procedures previously described (LaPatra et al. 1989).

DNA plasmid constructs. The open reading frames of the N, P, M, NV and G genes of IHNV isolate 039-82 (the WRAC strain) were amplified by reverse transcriptase-polymerase chain reaction using sequence specific primers (Morzunov et al. 1995) (IHNV isolate 039-82 genbank accession number L40883) and cloned into the pT7-blue vector (Novagen, Madison, WI). The genes were then subcloned downstream of the immediate-early enhancer-promoter sequences of human cytomegalovirus (CMV) of the pCDNA 3.1 vector (Invitrogen). The resulting plasmids, designated pCDNA$\mathrm{N}$, pCDNA-P, pCDNA-M, pCDNA-NV and pCDNA-G, contained the IHNV N, P, M, NV, and G genes respectively. The $\beta$-galactosidase construct (pCDNA- $\beta$-gal) was made by subcloning the $\beta$-galactosidase gene from the pCMV - gal vector (Anderson et al. 1996a) into pCDNA 3.1. All constructs were multiplied in Escherichia colis strain DH5 $\alpha$ cells grown in Luria broth media, and plasmid DNA was purified with anionexchange chromatography columns (Quiagen, Chastworth, CA). The N, P, M, NV, G and $\beta$-galactosidase ( $\beta$-gal) inserts in the constructs were sequenced at their $5^{\prime}$ and $3^{\prime}$ ends in order to insure the correct orientation and reading frame of the genes.

Confirmation of protein synthesis. The capacity of the plasmids to express the $\mathrm{G}, \mathrm{N}$ and $\beta$-gal proteins in vitro was assessed in transfected EPC cells. Two milliliters of EPC cells $\left(1 \times 10^{6}\right.$ cells $\left.\mathrm{ml}^{-1}\right)$ were plated onto laminin coated microscope glass slides (Sigma) and incubated in a $100 \mathrm{~mm}$ diameter petri-dish for $1 \mathrm{~h}$ at room temperature followed by the addition of $5 \mathrm{ml}$ of Opti-MEM medium (GIBCO). The slides were then incubated overnight at $25^{\circ} \mathrm{C}$ and transfected with $2 \mu \mathrm{g}$ of the appropriate DNA plasmid in lipofectamine prepared according to the manufacturer's protocol (GIBCO). The DNA-lipid complex was incubated with the cells for $24 \mathrm{~h}$. Following transfection, the DNA lipid complex was rinsed from the cells with RPMI-1640 medium (GIBCO) containing no fetal bovine serum or antibiotics. The cells were incubated in a sealed plastic container filled with a gas mixture containing $10 \%$ $\mathrm{mol} / \mathrm{mol}$ carbon dioxide, $10 \% \mathrm{~mol} / \mathrm{mol}$ oxygen and $80 \%$ nitrogen (Airgas, Portland, OR). Approximately $48 \mathrm{~h}$ after transfection, cells were rinsed with phosphate buffered saline (PBS; $\mathrm{pH} 7.4$ ) and fixed in cold acetone for 5 min ( $\mathrm{G}$ and $\mathrm{N}$ ) or $1 \%$ glutaraldehyde for 20 min ( $\beta$-galactosidase). The expression of the $G$ and $\mathrm{N}$ genes was confirmed by indirect immunofluorescence while the $\beta$-galactosidase activity was assessed by incubating transfected cells with X-gal solution $10.2 \% \mathrm{X}$-gal chromagen, $10 \mathrm{mM}$ sodium phosphate, $150 \mathrm{mM} \mathrm{NaCl}, 1 \mathrm{mM} \mathrm{MgCl}, 3.3 \mathrm{mM} \mathrm{K}_{4} \mathrm{Fe}(\mathrm{CN})_{6} \cdot 3 \mathrm{H}_{2} \mathrm{O}$, and $\left.3.3 \mathrm{mM} \mathrm{K}_{3} \mathrm{Fe}(\mathrm{CN})_{6}, \mathrm{pH} 7.0\right)$ at $37^{\circ} \mathrm{C}$ for $16 \mathrm{~h}$.

Indirect immunofluorescence. Transfected cells were incubated for $60 \mathrm{~min}$ in a mixture of 3 mouse monoclonal antibodies (mAbs) (1H8, 5A6 and 6A7) directed against the G protein of IHNV isolate 039-82 (Huang et 
al. 1996) or the mAb 1NDW14D directed against the IHNV N protein (Ristow et al. 1993). Cells were rinsed with PBS and reacted with an anti-mouse IgG goat fluorescein isothiocyanate labeled antibody (Sigma) for $60 \mathrm{~min}$. Cells were then rinsed with PBS and stained for 1 min with a $0.05 \%$ solution Evans blue. After addition of glycerol and a coverslip, cells were viewed under an epifluorescence microscope using a BP 450-490 nm filter.

Vaccination and bleeding of larger iish. Sockeye salmon Oncorhynchus nerka (mean weight $150 \mathrm{~g}$ ) were injected with $25 \mu \mathrm{g}$ of DNA in $200 \mu \mathrm{l}$ Tris-EDTA buffer and held in $369 \mathrm{l}$ aquaria at a temperature of $12^{\circ} \mathrm{C}$. Six weeks after vaccination, the fish were bled, sera were collected and neutralizing antibody titers were determined as previously described (LaPatra et al. 1993)

Passive immunization and challenge of rainbow trout fry. Rainbow trout (mean weight, 1 g) were anaesthetized by immersion in a $100 \mu \mathrm{g} \mathrm{ml}^{-1}$ concentration of tricaine methane sulfonate (MS-222; Argent Chemical Laboratories, Redmond, WAJ and were injected intraperitoneally with $50 \mu \mathrm{l}$ of pooled sera obtained from vaccinated sockeye salmon or with sterile PBS. Each treatment group was placed in a separate aquarium receiving ultraviolet-disinfected, single-pass spring water at a constant temperature $\left(15^{\circ} \mathrm{C}\right)$ for $24 \mathrm{~h}$. Duplicate groups of fish from each treatment were challenged with IHNV (isolate 220-90; LaPatra et al. $1991 \mathrm{~b})\left(10^{5} \mathrm{PFU} \mathrm{m} \mathrm{l}^{-1}\right)$ in an amount of water equalling 10 times the total weight of the fish, for $1 \mathrm{~h}$ in closed systems with aeration. Each group was then placed in a separate $19 \mathrm{l}$ aquarium and monitored for $21 \mathrm{~d}$ for mortality.

Vaccination, challenge and bleeding of rainbow trout fry. Rainbow trout (mean weight $2 \mathrm{~g}$ ) were anaesthetized as described above and injected intramuscularly at the base of the dorsal fin with 1,5 or $10 \mu \mathrm{g}$ of the appropriate DNA vaccine in $25 \mu \mathrm{l}$ Tris-EDTA buffer. Each treament group was placed in separate 19 to $32 \mathrm{l}$ aquaria at a temperature of $12^{\circ} \mathrm{C}$. Three to $6 \mathrm{wk}$ post-immunization, groups of 20 to 25 fish (in duplicate) representing each treatment were challenged by immersion in water containing $10^{5} \mathrm{PFU} \mathrm{ml^{-1 }}$ of IHNV isolate $220-90$ by standard procedures (LaPatra et al. $1991 \mathrm{~b}$ ). Fourteen and $16 \mathrm{~g}$ fish from the duration of protection experiment were challenged by intraperitoneal injection of $100 \mu \mathrm{l}$ solution of $10^{6} \mathrm{PFU} \mathrm{ml^{-1 }}$ of IHNV isolate $220-90$ at 58 and $80 \mathrm{~d}$ post-vaccination respectively. Average cumulative percent mortality was calculated for each experimental group. Experimental groups were held in separate 191 aquaria at a temperature of $15^{\circ} \mathrm{C}$, monitored 21 to $28 \mathrm{~d}$ for mortality, and fed ad libitum a dry pelleted diet (Clear Spring Foods, Inc.) daily. At least $20 \%$ of the fish that died on any given day were tested for virus. Rainbow trout fry used for the duration of protection experiment were bled in pools of 3 to 5 fish at Day 80 and in pools of 4 to 6 fish at Day 102 post-vaccination and their neutralizing antibody titers were determined.

\section{RESULTS}

\section{Expression of the IHNV proteins and control proteins in transfected cells}

Expression of the IHNV $N$ and $G$ proteins by plasmids pCDNA-N and pCDNA-G, respectively, was confirmed by immunohistochemical staining of EPC cells transfected with the DNA plasmids (Fig. 1). The pCDNA-N and pCDNA-G transfected cells reacted with the appropriate $N$ or $G$ specific antibodies. Similarly, cells transfected with pCDNA- $\beta$-gal were shown to express the $\beta$-galactosidase control protein (results not shown). Since the IHNV P, M and NV genes were cloned into the same vector using identical methods, we assume the plasmids pCDNA-P, pCDNA-M and pCDNA-NV were also competent to express these proteins, although this could not be confirmed due to the lack of monoclonal antibody reagents specific for these proteins, and the high background obtained in immunohistochemical staining with polyclonal IHNV antiserum (data not shown).

\section{Protection of fry from virus challenge 4 to $6 \mathrm{wk}$ post-vaccination}

Rainbow trout fry immunized with each vaccine construct were tested for protection against an IHNV immersion challenge at 4 to 6 wk post-immunization. In 3 consecutive experiments, rainbow trout fry immunized with 10,5 or $1 \mu \mathrm{g}$ of pCDNA-G exhibited significantly $(p<0.01)$ less mortality than fry vaccinated with the vector alone or with pCDNA- $\beta$-gal. Cumulative percent mortality in fish immunized with pCDNA$G$ ranged from 0 to $2 \%$ whereas mortality in fish immunized with DNA vaccines that contained other proteins or were left unhandled ranged from 36 to $76 \%$ (Table 1). There was no significant difference in mortality or mean day to death for fish immunized with pCDNA-N, pCDNA-M, pCDNA-P or pCDNA-NV relative to control vaccine groups. No mortality occurred in any of the mock infected control groups for each treatment that were not exposed to virus. At least $20 \%$ of the immunized fish from all groups that died following exposure to IHNV were tested for presence of IHNV in liver-kidney-spleen samples. In the 3 experiments virus was recovered from 94 to $98 \%(134 / 140)$ 


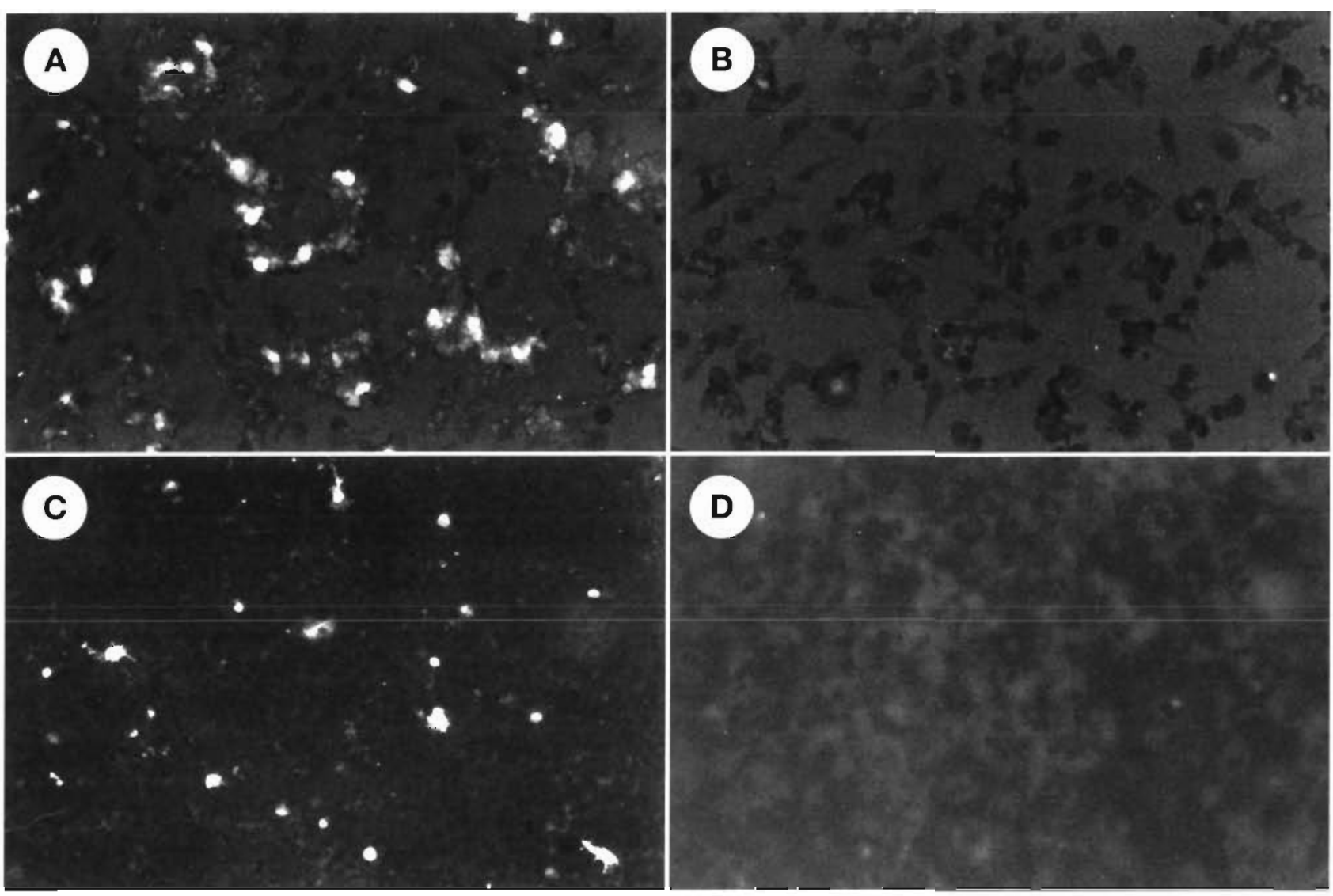

Fig. 1. Indirect immunofluorescence staining of the IHNV $N$ and $G$ proteins in cells transfected with either pCDNA-N or pCDNA-G, respectively. EPC cells were transfected with pCDNA-N (A), pCDNA-G $(C)$ or the control plasmid pCDNA- $\beta-g a l$ (B and $D$ ) and then probed with a $N$-specific mAb (1NDW14D) (A and B) or a mixture of G-specific mAbs (1H8, 5A6 and 6A7) (C and D). Cells were then reacted with an anti-mouse IgG goat FITC-labelled antibody

Table 1 Oncorhynchus mykiss. Survival of rainbow trout fry challenged with IHNV 4 to 6 wk post-vaccination in 3 consecutive experiments. na: not available

\begin{tabular}{|c|c|c|c|c|c|}
\hline Treatment & $\begin{array}{l}\mu \mathrm{g} \text { of DNA } \\
\text { per fry }\end{array}$ & $\begin{array}{c}\text { Weeks } \\
\text { post-vaccination }\end{array}$ & $\begin{array}{l}\text { No. dead } \\
\text { fry/total fry }\end{array}$ & $\begin{array}{c}\text { Mean cumulative } \\
\text { mortality }(\%)\end{array}$ & $\begin{array}{l}\text { Relative percent } \\
\text { survival (RPS) }^{b}\end{array}$ \\
\hline pCDNA-G & 10 & 6 & $0 / 44$ & $0^{c}$ & 100 \\
\hline pCDNA-M & 10 & 6 & $22 / 44$ & 50 & 14 \\
\hline pCDNA- $\beta$-gal & 10 & 6 & $14 / 39$ & 36 & 38 \\
\hline Vector alone & 10 & 6 & $18 / 42$ & 43 & 26 \\
\hline Unhandled & - & 6 & $28 / 48$ & 58 & Control \\
\hline pCDNA-G & 5 & 4 & $1 / 53$ & $2^{c}$ & 97 \\
\hline pCDNA-P & 5 & 4 & $23 / 49$ & 47 & 29 \\
\hline pCDNA- $\beta$-gal & 5 & 4 & $25 / 48$ & 52 & 21 \\
\hline Vector alone & 5 & 4 & $18 / 48$ & 38 & 42 \\
\hline Unhandled & - & 4 & $33 / 50$ & 66 & Control \\
\hline pCDNA-G & 1 & 4 & $1 / 49$ & $2^{c}$ & na \\
\hline $\mathrm{pCDNA}-\mathrm{N}$ & 1 & 4 & $38 / 50$ & 76 & na \\
\hline pCDNA-NV & 1 & 4 & $34 / 51$ & 67 & na \\
\hline pCDNA- $\beta$-gal & 1 & 4 & $29 / 48$ & 60 & na \\
\hline
\end{tabular}


Table 2. Oncorhynchus mykiss. IHNV challenge of vaccinated rainbow trout fry at extended time points post-vaccination

\begin{tabular}{|c|c|c|c|c|c|c|c|c|c|c|}
\hline \multirow{3}{*}{$\begin{array}{l}\operatorname{Time}^{a} \\
\text { (d) }\end{array}$} & \multirow{3}{*}{$\begin{array}{c}\text { Fish } \\
\text { size } \\
\text { (g) }\end{array}$} & \multirow{3}{*}{$\begin{array}{l}\text { Challenge } \\
\text { method }\end{array}$} & \multirow{2}{*}{\multicolumn{2}{|c|}{ pCDNA-N }} & \multirow{2}{*}{\multicolumn{2}{|c|}{$\begin{array}{l}\text { IHNV DNA vac } \\
\text { pCDNA-NV }\end{array}$}} & \multirow{2}{*}{\multicolumn{2}{|c|}{$\begin{array}{l}\text { treatments } \\
\text { pCDNA-G }\end{array}$}} & \multirow{2}{*}{\multicolumn{2}{|c|}{ pCDNA- $\beta-g a l$}} \\
\hline & & & & & & & & & & \\
\hline & & & $\begin{array}{l}\text { No. dead } \\
\text { fry/total fry }\end{array}$ & $\begin{array}{l}\text { Mean cumulat. } \\
\text { mortality }(\%)\end{array}$ & $\begin{array}{l}\text { No. dead } \\
\text { fry/total fry }\end{array}$ & $\begin{array}{l}\text { Mean cumulat. } \\
\text { mortality }(\%)\end{array}$ & $\begin{array}{l}\text { No. dead } \\
\text { fry/total fry }\end{array}$ & $\begin{array}{l}\text { Mean cumulat. } \\
\text { y mortality }{ }^{\mathrm{b}}(\%)\end{array}$ & $\begin{array}{l}\text { No. dead } \\
\text { fry/total fry }\end{array}$ & $\begin{array}{l}\text { Mean cumulat. } \\
\text { mortality }^{\mathrm{b}}(\%)\end{array}$ \\
\hline 28 & 6.8 & Immersion & $38 / 50$ & 76 & $34 / 51$ & 67 & $1 / 49$ & $2^{c}$ & $29 / 48$ & 60 \\
\hline 58 & 14 & Injection & $46 / 48$ & 96 & $26 / 50$ & 92 & $16 / 51$ & $31^{c}$ & $49 / 50$ & 98 \\
\hline 80 & 16 & Injection & $40 / 40$ & 100 & $39 / 41$ & 95 & $20 / 41$ & $49^{c}$ & $38 / 40$ & 95 \\
\hline \multicolumn{11}{|c|}{ 'Time post-vaccination } \\
\hline
\end{tabular}

of the dead fish examined, with mean titers of $10^{6.7}$ to $10^{6.9} \mathrm{PFU} \mathrm{g}^{-1}$ (range $10^{3.3}$ to $>10^{7.3} \mathrm{PFU} \mathrm{g}^{-1}$ ).

\section{Protection and neutralizing antibody activity in fry at extended time points post-vaccination}

Rainbow trout fry immunized with $1 \mu \mathrm{g}$ of either pCDNA-N or pCDNA-NV vaccines showed cumulative percent mortality ranging from 67 to $100 \%$ when challenged with IHNV at 28, 58 and $80 \mathrm{~d}$ post-immunization (Table 2). No significant difference in mortality was seen between pCDNA-N and pCDNA-NV groups compared with the pCDNA- $\beta$-gal vaccinated group of fry, which showed 60 to $98 \%$ cumulative mortality for the same time points (Table 2). In addition, pCDNA-G immunized fry exhibited a cumulative percent mortality of 2,31 , and $49 \%$ when challenged with IHNV at 28, 58 and $80 \mathrm{~d}$, respectively, post-immunization. Statistical analysis showed significant difference in mortality between the pCDNA-G group $(p<0.01)$ and the pCDNA- $\beta$-gal group at all time points (Table 2). Among rainbow trout challenged with IHNV, virus was recovered from $95 \%(157 / 165)$ of the fish that were examined. The mean IHNV concentration was $10^{6.87} \mathrm{PFU} \mathrm{g}^{-1}$ (range $10^{2.5}$ to $>10^{7.3} \mathrm{PFU} \mathrm{g}^{-1}$ ) in combined liver-spleen-kidney samples.

At 80 and 102 d post-immunization, IHNV neutralizing activity was absent from the sera of all non-challenged fry that were vaccinated with pCDNA-N $(0 / 23)$, pCDNA-NV $(0 / 22)$ and pCDNA- $\beta$ gal $(0 / 26)$ vaccines. No positive serum was detected in the pCDNA-G vaccinated fry at Day 80 post-immunization $(0 / 11)$. However, at Day 102 post-vaccination, 2 fry out of 11 showed antibody neutralizing titers of 20 and 80 (Table 3 ).

Neutralizing antibody titers were also determined from groups of pCDNA-G vaccinated trout that survived IHNV challenge at $22 \mathrm{~d}$ after immunization. All 16 challenge survivors tested at $80 \mathrm{~d}$ post-immunization had positive neutralizing antibody titers, with a mean titer of $>160$. Similarly, all 8 survivors tested at 102 d post-immunization were positive, with a mean titer of 80 .

\section{Virus neutralizing antibody activity in $150 \mathrm{~g}$ sockeye salmon}

Sockeye salmon vaccinated with $25 \mu \mathrm{g}$ of pCDNA-G had IHNV neutralization titers ranging from 80 to 320 at $6 \mathrm{wk}$ post-vaccination, indicating that these 5 fish responded specifically to IHNV. None of the 5 fish vaccinated with $\mathrm{pCDNA}-\mathrm{M}$ or the 4 control fish vaccinated with pCDNA- $\beta$-gal exhibited detectable neutralization titers (Table 4).

\section{Protection provided by pooled sera after passive immunization}

Rainbow trout fry were passively immunized with sera obtained from $150 \mathrm{~g}$ sockeye salmon that had been previously immunized with pCDNA-G or pCDNA- $\beta$-gal. Control fry were injected with buffer.

Table 3. Oncorhynchus mykiss. Anti-IHNV neutralizing antibody titers in vaccinated/unchallenged rainbow trout

\begin{tabular}{|c|c|c|c|c|}
\hline $\begin{array}{l}\text { Time } \\
\text { post- } \\
\text { vaccination } \\
\text { (d) }\end{array}$ & $\begin{array}{c}\text { pCDNA-N } \\
\text { Ratio (+) sera } \\
\text { /total sera }\end{array}$ & $\begin{array}{l}\text { HNV DNA va } \\
\text { pCDNA-NV } \\
\text { Ratio (+) sera } \\
\text { /total sera }\end{array}$ & $\begin{array}{l}\text { cine treatments } \\
\text { pCDNA-G } \\
\text { Ratio (+) sera } \\
\text { /total sera }\end{array}$ & $\begin{array}{c}\text { pCDNA- } \beta-g a] \\
\text { Ratio (+) sera } \\
\text { /total sera }\end{array}$ \\
\hline $80^{\circ}$ & $0 / 12$ & $0 / 12$ & $0 / 11$ & $0 / 12$ \\
\hline $102^{b}$ & $0 / 11$ & $0 / 10$ & $\begin{array}{c}2 / 11 \\
(20,80)^{c}\end{array}$ & $0 / 14$ \\
\hline \multicolumn{5}{|c|}{$\begin{array}{l}{ }^{a} \text { Fish were bled in pools of } 3 \text { to } 5 \\
{ }^{b} \text { Fish were bled in pools of } 4 \text { to } 6 \\
{ }^{c} \text { Anti-IHNV neutralizing antibody titers }\end{array}$} \\
\hline
\end{tabular}


Table 4. Oncorhynchus nerka. Anti-IHNV neutralizing antibody titers detected in individual adult sockeye salmon vaccinated with plasmid DNA

\begin{tabular}{|lcc|}
\hline Vaccine & $\begin{array}{c}\text { Fish } \\
\text { no. }\end{array}$ & $\begin{array}{c}\text { Neutralizing } \\
\text { titer }^{\mathrm{a}}\end{array}$ \\
\hline pCDNA-G & 1 & 80 \\
pCDNA-G & 2 & 320 \\
pCDNA-G & 3 & 320 \\
pCDNA-G & 4 & 160 \\
pCDNA-G & 5 & 160 \\
pCDNA-M & $1-5$ & $<20$ \\
pCDNA- $\beta$-gal & $1-4$ & $<20$ \\
antibody titers are reported as the reciprocal of the high- & \\
est dilution that resulted in a 50\% reduction in the aver- \\
age number of plaques detected in the negative control \\
wells
\end{tabular}

Following immersion challenge with IHNV, fry immunized with pCDNA-G and pCDNA- $\beta$-gal had relative survivals of 100 and $58 \%$, respectively, compared to control fry (Table 5). No mortality was recorded in the non-infected fry control groups. Among rainbow trout challenged with IHNV, virus was recovered from $97 \%(37 / 38)$ of the fish that were examined. The mean IHNV concentration was $10^{6.6} \mathrm{PFU}^{-1}$ (range $10^{2.5}$ to $>10^{7.3}$ PFU $\mathrm{g}^{-1}$ ) in combined liver-spleenkidney samples.

\section{DISCUSSION}

The goal of this study was to evaluate the protective immunogenicity of individual IHNV proteins expressed by DNA vaccines. In the first set of experiments, the pCDNA-G vaccine induced significant protection in

Table 5. Oncorhynchus mykiss. Susceptibility of naïve rainbow trout fry to IHNV immersion challenge after passive immunization with vaccinated salmon sera. RPS: relative percent survival

\begin{tabular}{lcc|}
$\begin{array}{l}\text { Passive } \\
\text { immunization } \\
\text { treatment }\end{array}$ & $\begin{array}{c}\text { IHNV-exposed } \\
\text { fry mean cumulative } \\
\text { mortality }(\%)\end{array}$ & $\begin{array}{c}\text { Relative percent } \\
\text { survival } \\
\text { (RPS) }^{\mathrm{b}}\end{array}$ \\
\hline pCDNA-G & $0(0 / 47)$ & 100 \\
pCDNA- $\beta-g a l$ & $25(12 / 49)$ & 58 \\
PBS & $69(33 / 48)$ & - \\
Unhandled & $59(27 / 46)$ & Control \\
'There was no significant statistical variation amongst \\
duplicate groups; hence the results were combined for \\
each treatment and cumulative percent mortality was \\
reported as a mean. Numbers in parentheses: no. of dead \\
fry/total no. of fry \\
'RPS $=(1-\%$ mortality of vaccinated fry/\% mortality of \\
control fry) $\times 100$
\end{tabular}

rainbow trout fry with relative survival ranging from 97 to $100 \%$. This confirms the previous report of protection induced by an IHNV G DNA vaccine in rainbow trout fry (Anderson et al, 1996b). The other viral proteins of IHNV (N, P, M and NV) that were tested did not induce any significant level of protection in fry since the mean cumulative mortality of fish immunized with the pCDNA-M, pCDNA-P, pCDNA-N and pCDNA-NV vaccines did not differ statistically from the pCDNA- $\beta$-gal or vector alone negative control vaccines. These results suggest that no specific or nonspecific immune response was induced by these viral vaccines.

Although only the G protein of IHNV is known to elicit a neutralizing antibody response in fish (Engelking \& Leong 1989), we anticipated some level of protection from vaccination using other viral proteins, possibly as a result of the induction of other immune mechanisms. For instance, Oberg et al. (1991) showed an augmentation in the efficacy of a recombinant fusion $G$ subunit protein vaccine against IHNV by addition of the $\mathrm{N}$-fusion protein to the vaccine preparation. Furthermore, a study by Lorenzen et al. (1998) showed partial protection in $13 \mathrm{~g}$ rainbow trout immunized with a DNA vaccine encoding the nucleocapsid $\mathrm{N}$ gene of VHSV. In contrast, Anderson et al. (1996b) reported no improvement in the survival rate of fish vaccinated with a pCMV-4-N DNA vaccine alone. However, they did show augmentation of the antibody response when the N DNA vaccine was included with the IHNV G DNA vaccine. These findings taken together led us to expect a better efficacy of the pCDNA-N vaccine used in our study. The lack of protection of fry immunized with our pCDNA-N vaccine confirmed the observation of Anderson et al. (1996b) and contrasts with the partial protection seen with the pCDNA-N vaccine of VHSV (Lorenzen et al. 1998). The difference in fish size at the time of immunization may account for such contrasting results, or it may be that, unlike VHSV, IHNV N protein does not present the appropriate immunogenic epitopes to induce a protective immunity in trout. The absence of protection against viral challenge in the groups of fish vaccinated with the pCDNA-N, pCDNA-P, pCDNA-M, and pCDNA-NV constructs, as well as the absence of neutralizing antibody titers, suggested that these proteins are poorly immunogenic to fish when formulated as DNA vaccines. However due to the absence of confirmation of specific viral protein expression from the pCDNA-P, pCDNA-M, and pCDNA-NV constructs we cannot rule out the possibility that the lack of detectable immune response to these plasmids was due to lack of expression of the viral proteins. Further tests are required to confirm the lack of immunogenicity of the internal proteins of IHNV. 
Based on our first results, we established a time course experiment that would shed some light on the duration of protection conferred by the pCDNA-G vaccine and would also confirm the lack of efficacy of 2 other constructs, pCDNA-N and pCDNA-NV, at inducing protection in fingerling rainbow trout. Results showed that up to $98 \%$ of the fish were protected at $28 \mathrm{~d}$ post-immunization. Significant protection was also conferred by the pCDNA-G vaccine at 58 and $80 \mathrm{~d}$ compared to the pCDNA- $\beta$-gal vaccine despite the intraperitoneal injection, a much more potent method of challenge necessary to overcome the natural immunity to IHNV that larger trout develop. In contrast, the $N$ and $N V$ vaccines did not show any improvement in protection at the 3 time points tested, demonstrating that longer 'incubation' periods did not improve the vaccines efficacy. In order to assess whether neutralizing antibody could be produced in immunized rainbow trout fry we analyzed sera at 80 and $102 \mathrm{~d}$ post-immunization. Among all groups, only 2 out of 11 trout vaccinated with the $G$ vaccine had detectable IHNV neutralizing antibody titers. It is not clear why only a few fish responded; however, the genetic heterogeneity of outbred trout population used in our experiments may be a factor in this phenomenon. Neutralizing antibody titers were detected in all fry vaccinated with pCDNA$G$ that survived challenge against IHNV. In this case, it is most likely that the virus itself was responsible for the induction of neutralizing antibodies.

It has been shown that exposure of rainbow trout to live IHNV can induce neutralizing antibody titers ranging from 40 to $\geq 2560$ (LaPatra et al. 1993). Our results showed that neutralizing antibody titers present in the sera of $150 \mathrm{~g}$ sockeye salmon immunized with pCDNA-G ranged from 80 to 320 . The protection against IHNV provided by these sera to naive fry suggests that neutralizing antibodies are involved in the protection of fish conferred by the pCDNA-G vaccine. However, in other studies the sera of salmonid fish immunized with the pCMV-4-G vaccine did not show detectable levels of neutralizing antibody and yet protected passively immunized naïve fry against IHNV challenge (unpubl. results). In addition, it has been shown that antibodies can be protective in fish (Lorenzen et al. 1990) or in mice (Corbeil et al. 1996) without being able to neutralize viral particles in cell culture. We therefore cannot exclude the influence of other mechanisms in the protection observed in our passively immunized fry. The relatively low percent of mortality observed in fry passively immunized with the sera of sockeye salmon vaccinated with the pCDNA- $\beta$-gal negative control vaccine compared to the higher percent mortality observed in PBS and unhandled fish groups may be due to a nonspecific activity triggered either by the sockeye salmon serum itself or by the $\beta$-gal protein.
In summary, our results have clearly shown that, when expressed by a DNA vaccine construct, neither the internal structural proteins ( $N, P$ and $M$ ) nor the NV protein of IHNV induce protective immunity in fry and do not induce the production of neutralizing antibodies in large fish (unpubl. results). The G protein, however, does confer near to complete protection in fry and induces neutralizing antibodies in large fish as well as in some rainbow trout fry. Upon passive transfer, these antibodies confer protection to naive fry against IHNV. To better understand the immune response of rainbow trout upon immunization with the pCDNA-G vaccine, we are currently investigating non-antibody dependent mechanisms that may contribute to the protection conferred against IHNV.

Acknowledgements. We wish to thank Dr J. R. Winton for numerous valuable discussions and expert photographic assistance. We also thank Sunshine Walker and Bill Shewmaker (both from Clear Springs Foods, Inc.) and Bill Batts (from the Western Fisheries Research Center) for their invaluable technical assistance. This work was supported by NRICGP/USDA award number 103936, and by the Western Fisheries Research Center, Biological Resources Division, U.S. Geological Survey, through the Washington Cooperative Fish and Wildlife Research Unit. The Washington Cooperative Fish and Wildlife Research Unit is supported by the USGS, University of Washington, and the Washington Department of Ecology, Fish and Wildlife, and Natural Resources.

\section{LITERATURE CITED}

Anderson ED, Mourich DV, Leong JC (1996a) Gene expression in rainbow trout (Oncorhynchus mykiss) following intramuscular injection of DNA. Mol Mar Biol Biotechnol 5(2): 105-113

Anderson ED, Mourich DV, Fahrenkrug SC, LaPatra SE Shepherd J, Leong JC (1996b) Genetic immunization of rainbow trout (Oncorhynchus mykiss) against infectious hematopoietic necrosis virus. Mol Mar Biol Biotechnol 5(2): $114-122$

Boudinot P, Blanco M, de Kinkelin P, Benmansour A (1998) Combined DNA immunization with the glycoprotein gene of viral hemorrhagic septicemia virus and infectious hematopoietic necrosis virus induces double-specific protective immunity and nonspecific response in rainbow trout. Virology 249:297-306

Corbeil S, Seguin C. Trudel M (1996) Involvement of the complement system in the protection of mice from challenge with respiratory syncytial virus Long strain following passive immunization with monoclonal antibody 18A2B2. Vaccine 14(6):521-525

Engelking HM, Leong JC (1989) Glycoprotein from infectious hematopoietic necrosis virus (IHNV) induces protective immunity against five IHNV types. J Aquat Anim Health $1: 291-300$

Fijan N, Sulimanovic D, Bearzotti M, Muzinic D, Zwillenberg LO, Chilmonczyk S, Vautherot JF, de Kinkelin P (1983) Some properties of the Epithelioma papulosum cyprini (EPC) cell line from carp Cyprinus carpio. Ann Virol (Inst Pasteur) 134E:207-220 
Fooks AR, Jeevarajah D, Warnes A, Wilkinson GWG, Clegg JCS (1996) Immunization of mice with plasmid DNA expressing the measles virus nucleoprotein gene. Viral Immunol 9(2):65-71

Huang C, Chien MS, Landolt M, Batts W, Winton J (1996) Mapping the neutralizing epitopes on the glycoprotein of infectious haematopoietic necrosis virus, a fish rhabdovirus. J Gen Virol 77:3033-3040

Lannan CN, Winton JR, Fryer JL (1984) Fish cell lines: establishment and characterization of nine cell lines from salmonids. In Vitro 20(9):671-676

LaPatra SE, Roberti KA, Rohovec JS, Fryer JL (1989) Fluorescent antibody test for the rapid diagnosis of infectious hematopoietic necrosis. J Aquat Anim Health 1:29-36

LaPatra SE, Lauda KA, Jones GR, Walker S (1991a) Standardization of infectious hematopoietic necrosis virus challenge procedures. Am Fish Soc Fish Health Section Newsletter $19(4): 3-5$

LaPatra SE, Lauda KA, Morton AW (1991b) Antigenic and virulence comparison of eight isolates of infectious hematopoietic necrosis virus from the Hagerman Valley, Idaho, USA. In: Fryer JL (ed) Proceedings of the Second International Symposium on Viruses of Lower Vertebrates. Oregon State University, Corvallis, Oregon, p 125-129

LaPatra SE, Turner T, Lauda KA, Jones GR, Walker S (1993) Characterization of the humoral response of rainbow trout to infectious hematopoietic necrosis virus. J Aquat Anim Health 5:165-171

Lorenzen N, Olesen NJ, Jorgensen PEV (1990) Neutralization

Editorial responsibility: Jo-Ann Leong,

Corvallis, Oregon, USA of Egtved virus pathogenicity to cell cultures and fish by monoclonal antibodies to the viral G protein. J Gen Virol $71: 561-567$

Lorenzen N, Lorenzen E, Einer-Jensen K, Heppell J, Wu T, Davis H (1998) Protective immunity to VHS in rainbow trout (Oncorhynchus mykiss, Walbaum) following DNA vaccination. Fish Shellfish Immunol 8:261-270

Morzunov SP, Winton JR, Nichol ST (1995) The complete genome structure and phylogenetic relationship of infectious hematopoietic necrosis virus. Virus Res $38(2-3)$ : $175-192$

Oberg LA, Wirkkula J, Mourich D, Leong JC (1991) Bacterially expressed nucleoprotein of infectious hematopoietic necrosis virus augments protective immunity induced by the glycoprotein vaccine in fish. $J$ Virol 65:4486-4489

Paul WE (1999) Fundamental immunology, 4th edn. Lippincott-Raven, Philadelphia, p 1021-1049

Ristow SS, de Avila J, LaPatra SE, Lauda K (1993) Detection and characterization of rainbow trout antibody against infectious hematopoietic necrosis virus. Dis Aquat Org 15: $109-114$

Ulmer JB, Donnelly JJ, Parker SE, Rhodes GH, Felgner PL, Dwarki VJ, Gromkovwski SH, Deck RR, Dev CM, Friedman A, Hawe LA, Leander KR, Martinez D, Perry HC, Shiver JW, Montgomery DL, Liu MA (1993) Heterologous protection against influenza by injection of DNA encoding a viral protein. Science 259:1745-1749

Yokoyama M, Zhang J, Whitton JL (1995) DNA immunization confers protection against lethal lymphocytic choriomeningitis virus infection. J Virol 69:2684-2688

Submitted: May 4, 1999; Accepted: July 9, 1999

Proofs received from author(s): December 7, 1999 